Article

\title{
Contingency and Political Action: The Role of Leadership in Endogenously Created Crises
}

\author{
András Körösényi *, Gábor Illés and Rudolf Metz \\ Institute for Political Science, Centre for Social Sciences, Hungarian Academy of Sciences, 1014 Budapest, Hungary; \\ E-Mails: korosenyi.andras@tk.mta.hu (A.K.), illes.gabor@tk.mta.hu (G.I.), metz.rudolf@tk.mta.hu (R.M.) \\ * Corresponding author
}

Submitted: 15 December 2015 | Accepted: 5 April 2016 | Published: 23 June 2016

\begin{abstract}
Among the recent literature about leadership and crisis situations two main strands are to be observed: structuralist ones mainly treat political leaders as reactive agents who have relatively little room for maneuver, while constructivist ones put greater emphasis on the opportunities in interpreting crises. Our claim is that there is a third analytical possibility mainly neglected in recent literature that is even more voluntaristic than the constructivist approaches. In this scenario, there is no external shock; leaders do not only interpret, but also "invent" crises. To make our claim plausible, we build a conceptual-descriptive typology of the potential relationships between crisis situations and agency. The typology is founded on Kari Palonen's differentiation between Machiavellian and Weberian types of contingency, but uses his originally conceptual historical argument for analytical purposes. To underpin our theoretical argument, we present short illustrative examples to all three types of crisis scenarios (the structuralist, the constructivist, and the voluntarist one).
\end{abstract}

\section{Keywords}

Bush; contingency; crisis; leadership; Machiavelli; Orbán; Weber

\section{Issue}

This article is part of the issue "New Approaches to Political Leadership", edited by Mark Bennister (Canterbury Christ Church University, UK).

(C) 2016 by the authors; licensee Cogitatio (Lisbon, Portugal). This article is licensed under a Creative Commons Attribution 4.0 International License (CC BY).

\section{Introduction}

Great leaders need crisis situations to gain power to (re)act (Genovese, 1979; Rossiter, 1948), but crisis situations need great leaders in order to be solved as well (Tucker, 1968, p. 745,1981 ). To put a twist on that paradox: there are two extreme ways to perceive and conceptualize extraordinary situations and to deal with them. On the one hand, a crisis could be seen as an exogenously given situation for leaders to manage in a technocratic or conventional way; on the other, it can be seen as a situation generated endogenously by leaders acting in an innovative way. While researchers usually explore leaders' responses to exogenous crises, such as industrial accidents, natural catastrophes, ter- rorist attacks or responses to economic or international financial crises, our focus is on endogenously generated and/or shaped crises. The first goal of this paper is to emphasize the role of political agency in crisis generation and in re-defining it, something that is very much neglected by approaches focusing on structural determinants. Secondly, the paper aims to provide a general conceptual typology of the relation between political agency and crisis.

The problem arises from the structure-agency debate. "Agency" is usually understood as a capacity to act intentionally, voluntarily upon situations, as a property of actors to be able to formulate and implement decisions. On the other hand, "structure" means the situation, context and political environment. It re- 
fers to the conditions within which actors operate and seize the opportunities, and which determine or constrain their actions. Essentially, structure and agency are two sides of the same coin, as they coexist in a political process. (Hay, 2002, pp. 89-135). A fundamental problem for political leadership studies is how the relationship between the political actors and the environment in which they find themselves is managed. Calls for research into the dilemma of the structure-agency problem in leadership studies are not new (Hargrove, 2004; Jones, 1989; Masciulli, Molchanov, \& Knight, 2009; 't Hart \& Rhodes, 2014). In this paper, we will encounter the structure-agency problem in a more concrete setting, that of crises and extraordinary situations. In a crisis situation, where leadership differs from agency in ordinary times, this dualism is more problematic. At least three different perspectives can be distinguished within the literature concerning the relationship between structure and agency in crisis. Firstly, the structuralist approach moves within a challenge/reaction scheme, where the change of structure triggers agency (Structure $\rightarrow$ Agency). For structuralist authors crisis means a more or less objective situation for agents, i.e. political leaders remain in a reactive role. As Ronald A. Heifetz (1994) notes, leaders define the problem, decide how to tackle it, and then work towards adaptation of either values, reality or both. Leadership is triggered by the emergence of complex problems. For Boin, McConnell and 't Hart (2008) crises are triggered in a variety of ways, but always by external or exogenous forces (natural catastrophes, malfunctions of a society's sociotechnical and political administrative systems, or by internal or external enemies), or political scandals (Boin et al., 2008, p. 3). Recently, Jim Buller and Toby S. James (2015) have argued for the analytical primacy of structure on the grounds of philosophical realism. They have emphasized the role of 'emergent properties' of previously unrelated structures that often result in outcomes that are unanticipated and difficult to control for the agents.

Secondly, constructivists attribute a greater role to political leaders in shaping the situation and they transcend the challenge/reaction scheme. They emphasize the intersubjective factors of a crisis situation: crisis is interpreted by political actors for the broader public (Structure $\leftarrow \rightarrow$ Agency). As Mark Blyth (2003) argues, "structures do not come with an instruction sheet", and even exogenous shocks must be interpreted to have a meaning for the people and for politicians as well. Keith Grint is interested in the processes "through which decision-makers persuade their followers, and perhaps themselves, that a certain kind of action is required". He adds that "...leadership involves the social construction of the context that both legitimates a particular form of action and constitutes the world in the process.... [The question is] not what is the situation, but how it is situated." (Grint, 2005, pp.
1469-1471, italics original). Wesley W. Widmaier and his colleagues aim to give a "constructivist analysis of wars and crises, which we define as events which agents intersubjectively interpret as necessitating change." (Widmaier, Blyth, \& Seabrooke, 2007, p. 748). Recalling historical cases Joseph S. Nye emphasizes that "...leaders sometimes help to enlarge a crisis and exacerbate the distress that triggers the process of charisma creation" (Nye, 2008, p. 57).

A third perspective, usually neglected in the literature, is the role of agency beyond interpreting an external shock, that is generating crises (Structure $\leftarrow$ Agency). This missing case emerges in politics if the radicalized version of the constructivist approach is accompanied with a robust role of voluntarist political agency, where the crisis is "invented" by the agent(s). Intersubjective processes of "meaning making" begin to play a role after this invention took place. As Hook's (1957) concept of the "event-making man" evaporated from the literature, this robust role of political agents is taken into consideration only in connection with revolutionary leaders. Robert $C$. Tucker notes that in the case of revolutionary leaders we can see "...how an act of leadership can be self-fulfilling: it can help bring about the very situation that the leader has diagnosed as already existing." (Tucker, 1981, p. 113). The first aim of this paper is to highlight the role of leadership in endogenously created crises.

But what if we conceive these perspectives as just different types of relations between leaders and crisis situations? In that case, bringing together those perspectives would be a legitimate goal, because each can be useful in enlightening different types of crises. Bearing this in mind, the second aim of this paper is to establish a conceptual typology that is able to incorporate all these approaches. Our central concept in this typology is contingency. Relying heavily on the works of Kari Palonen $(1998,2001)$, we describe contingency as the nature of relations between structure and agency. Contingency can serve both as a constraint on political action (as in The Prince of Machiavelli) as well as a means for such action (as in the works of Max Weber). We take crisis, as a situation with an extraordinarily high level of contingency, to highlight this "dual nature" of contingency for political agency. This concept, in our view, is suitable to soften the rigidity of the structureagency dualism. In this paper we focus on incumbent leaders, who lead crisis governments (Corwin, 1978, p. 78; Edinger, 1967, p. 15, 1975, p. 257; Kellerman, 1984, p. 71; Rossiter, 1948, p. 3) and who make things happen that would not happen otherwise (Blondel, 1987, p. 3; Cronin, 1980, p. 372; McFarland, 1969, p. 155).

Based on this conceptual framework, our paper provides a general typology of contingency, i.e. the relationship between political agency (leadership) and structure/structural change (crisis), and sets out empirical examples within it. Such a typology can serve gen- 
erally "as a heuristic device to enable us to understand why those charged with decision-making sometimes appear to act in ways that others find incomprehensible." (Grint, 2005, p. 1475). More concretely, it can help in (1) mapping different perspectives concerning the relationship between structural factors and agency during crises; (2) to revitalize a somewhat neglected third perspective noted above.

The paper is structured as follows. First, we define the concept of crisis and give a conceptual differentiation related to contingency. Second, we analyse the possible relationships between contingency and political action and differentiate between two types of contingency, drawing on Palonen's comparison of the Machiavellian and the Weberian Moments. Third, we develop a fourfold typology of the relationship between political agency and different states of affairs: normalcy and three different types of crisis. Each type will be highlighted through empirical examples. Finally, we draw a few conclusions.

\section{Crisis and Contingency}

First of all, we need to clarify what we mean by crisis. One of the recent papers on crisis and leadership defined the former with three criteria: threat, uncertainty, and urgency (Boin, 't Hart, Stern, \& Sundelius, 2005). By threat we mean high-stake politics, which characterizes crises, vis-a-vis low-stake politics in normal times. Urgency here means a commanding necessity of action in the case of crisis, which is absent in the case of normality, when the pressure for urgent action is not present or low. In this paper, we focus mainly on the second component, uncertainty, identifying it as a subtype of a broader concept, contingency. Contingency can mean indeterminacy ("It could be different"), or uncertainty ("We cannot know") (Schedler, 2007). We assume that contingency is present both in states of the normal functioning of politics and in times of crisis. But while in the former it is usually indeterminacy, in crisis situations it can rather be characterized as uncertainty. The factor that distinguishes the two is the presence (in case of indeterminacy) of rules, conventions and authorities that reduce the spectrum of possible choices. The formulation of Michael Oakeshott properly describes indeterminacy in the normal state of affairs:

"But in stipulating general conditions for choosing less incidental than the choices themselves, in establishing relationships more durable than those which emerge and melt away in transactions to satisfy a succession of contingent wants, and in articulating rules and duties which are indifferent to the outcome of the actions they govern, it may be said to endow human conduct with a formality in which its contingency is somewhat abated." (Oakeshott, 1990, p. 74)
In a crisis situation it is precisely these "rules and duties" (and conventions, authorities) that become dubious, thereby making the political situation uncertain. ${ }^{1}$

The difference in the nature of uncertainty from that of indeterminacy can also be highlighted by the Knightian conceptual differentiation between risk and uncertainty familiar from economics. While risk is measurable and calculable (because conditions are known, as in the case of roulette or chess, or generally in game theory), uncertainty is not (because conditions are not known, and we cannot make predictions). Therefore, it is not only the higher intensity, but the different nature of contingency that differentiates crisis situations from normal states Uncertainty, rather than risk, characterizes crisis and extraordinary situations.

In section 3, drawing on Kari Palonen's work, we will try to relate the concept of contingency to that of agency. Thereafter (in section 4), relying on Palonen's differentiation between two types of contingency (Machiavellian and Weberian) we try to set up a twodimensional theoretical framework for analyzing crisis situations and types of political action. The typology provides not only a useful analytical framework, but reveals the role of leadership in the case of endogenously created crises, which is neglected in the literature. We claim that crises and exceptional situations might be engendered endogenously, by political agency.

\section{Palonen's Distinction: Background vs. Operative Contingency ${ }^{2}$}

To establish a connection between contingency and political agency, we use a work by Kari Palonen (1998) as a point of departure. Palonen differentiates between the "Machiavellian Moment" (cf. Pocock, 1975) and what he calls the "Weberian Moment". His main argument, roughly summarized, is that while in the

\footnotetext{
1 This difference can be exemplified by two different uses of the same metaphor. In Michael Oakeshott's famous formulation, politicians "sail a boundless and bottomless sea" where the "enterprise is to keep afloat on an even keel" (Oakeshott, 1991, p. 60). This can be taken as the general characterization of political activity that also applies in the normal state of politics. The other use can be taken as a paradigm of crisis: politicians in crisis resemble "river oarsmen who...suddenly find themselves called upon to navigate their boat in mid-ocean" (Tocqueville, 1896, p. 106).

2 Our reading here relies heavily on Kari Palonen's distinction between Machiavelli and Weber, a distinction to be made clear at the end of this section. His reading, in our view, has great analytical merits, but The Prince can also be interpreted in a different way, i.e. as a work that supposes a more complex relationship between fortuna and virtú (see e.g. Pocock, 1975, pp. 156-182), or one that lays a greater emphasis on agency and character, and therefore rather stresses the similarities between the views of Machiavelli and Weber (see e.g. Philp, 2007, pp. 37-96). However, here our point of interest lies not in conceptual historical accuracy, but in analytical usefulness.
} 
former contingency is mainly an external challenge for political action, in the latter it becomes its constitutive element. Here we try to summarize briefly the differences between these two "Moments" (see Table 1). These considerations will serve as the foundation of our typology concerning the relationship between political agency and crises.

(1) The background of political action in the Machiavellian Moment is uncertain. The main problem of The Prince is the retention of principalities newly acquired through the arms of others and through good fortune. As Machiavelli emphasizes, these cases are when the situation of the rulers is the most difficult, because they cannot rely on traditional legitimacy, only on the "two most inconstant and unstable things". The factors that would nudge uncertainty into indeterminacy are apparently missing. Contrary to that, the historical context of Weber's work is a marked by bureaucratization, which forms a stable background to political action, abating contingency by its rules and standard procedures.

(2) For Machiavelli, the main threat that political action must face is the desolation of fortuna, which is compared by him to "raging rivers" in Chapter 25 of The Prince. For Weber, the main problem consists not in taming the forces of fortuna, but in avoiding the "petrification" of bureaucratic structures. Put differently: his main concern is with the possibility of politics, not with that of order (Palonen, 2001). The difference between the two authors is aptly expressed by their uses of metaphors: while Machiavelli's prince has to erect "defences and barriers, in such a manner that, rising again, the waters may pass away by canal, and their force be neither so unrestrained nor so dangerous" (Machiavelli, 2008, Chapter 25), Weber describes politics as a "strong and slow boring of hard boards" (Weber, 2001, p. 128). The latter in Palonen's interpretation means the opening up of new horizons for political action.

(3) The first, vital task for leaders follows from the above-mentioned features. For Machiavelli's prince, it is mantenere lo stato, that is, to maintain his power and the present form of government. There is undeniably an element of innovation in the Machiavellian view: his image of the fox (Machiavelli, 2008, Chapter 18) implies that fortuna can not only be contained, but also utilized to a certain degree, but-at least in Palonen's interpretation-this is a secondary feature; the main concern is still with the exposedness to and the preponderance of fortuna. For Weber, the first task of a political leader is to create room for manoeuvre among bureaucratic constraints.

(4) It is worth mentioning that both views of political action can take pathological forms. For Machiavelli, mantenere lo stato without some higher aims that bring glory to the prince and benefit to his subjects is detestable (cf. Skinner, 2002, pp. 143-144). In the same vein, Weber is no advocate of adventurous politics that takes risks for their own sake. Although he is worried about the growth of bureaucratic influence, at the same time he also admits its importance as a stable background as far as the possibility of politics can be guaranteed.

(5) As we mentioned before, the main thesis of Palonen's book concerns the position switch of contingency. While in the Machiavellian Moment it is principally (despite the presence of the figure of the fox) external to political action, a challenge that has to be overcome, in the Weberian Moment it becomes an element of political action itself. Where the foremost danger is seen in the ravaging power of fortuna (a symbol of contingency), politics is logically directed against contingency. But in a bureaucratized world contingency is linked with freedom from the bureaucratic structure. Therefore, politicians act not against, but through contingency.

(6) As the last point implicates, contingency changes from a background condition (fortuna) into an operative element. This distinction between background and operative contingency will form the basis of our analytical typology of the relationship between political action and crisis presented in the next part.

Table 1. Comparison of the Machiavellian and the Weberian moment.

\begin{tabular}{|c|c|c|}
\hline & Machiavellian Moment & Weberian Moment \\
\hline Background of political action & Uncertain (newly acquired rule) & Stable (age of bureaucratization) \\
\hline Main threat & External shocks (fortuna) & $\begin{array}{l}\text { Stagnation, "petrification" of } \\
\text { bureaucratic structures }\end{array}$ \\
\hline Main task of the leader & $\begin{array}{l}\text { Reduce contingency, assure security } \\
\text { and order (metaphor: erecting } \\
\text { "defences and barriers") }\end{array}$ & $\begin{array}{l}\text { Create room for manoeuvre } \\
\text { (metaphor: "boring of hard boards") } \\
\text { through increasing contingency }\end{array}$ \\
\hline Pathological form & Mere defence of the status quo & $\begin{array}{l}\text { Constant subversion, irresponsible } \\
\text { action that endangers the state }\end{array}$ \\
\hline $\begin{array}{l}\text { Connection between action and } \\
\text { contingency }\end{array}$ & $\begin{array}{l}\text { Acting against contingency (politics = } \\
\text { Spiel gegen die Kontingenz) }\end{array}$ & $\begin{array}{l}\text { Acting through contingency (politics = } \\
\text { Spiel durch die Kontingenz) }\end{array}$ \\
\hline Types of contingency & $\begin{array}{l}\text { Background contingency (Kontingenz } \\
\text { des Handelns) }\end{array}$ & $\begin{array}{l}\text { Operative contingency } \\
\text { (Kontingenz im Handeln) }\end{array}$ \\
\hline
\end{tabular}




\section{An Analytical Typology and Empirical Examples}

Up to this point, we have claimed that (1) a crisis situation is marked by the presence of a subtype of contingency: uncertainty; and (2) that contingency can be both the background condition and a constitutive element of political agency. In this section, first, we will set up an analytical typology of the relationship between political agency and crisis, thereby interrelating the two above-mentioned conceptual distinctions. Second, we will give empirical examples to make our typology more plausible. Our focus will be on the working of operative contingency through re-interpretation of a hitherto exogenous understanding of crisis (quadrant C) and through endogenous crisis-generation by creative political agency (quadrant D). Although there are no clear cases, we hope our examples will help to clarify the difference between operative and background contingency.

The conceptual analysis of contingency by Palonen provides an appropriate starting point to construct an analytical typology of the relationship between political agency and crisis. The two types of contingency form the two dimensions of the matrix in Table 2. As mentioned before, we assume-following Oakeshott-that there is contingency in every political situation. However, where both types of contingency are low, we can speak of a normal state of affairs (quadrant A). Here conventions (using the term in the broadest sense, including the usual procedures, behavioural patterns of politicians, the legal order etc.) are challenged neither by an exogenous shock nor by political agents. In the three other quadrants, the sum of the two types of contingency are higher; therefore in these cases we can speak of crisis situations. ${ }^{3}$

3 A clarifying note: for Weber, in contrast to the Kairosthinkers, the distinction between normal and extraordinary situations is not an important one: political chances are ubiquitous. However, when Weber denies the importance of extraordinary situations, he speaks of them as prerequisites for political action; while in quadrant $\mathrm{C}$ and especially in quadrant D of our typology, crises or extraordinary situations are rather the outcomes of political action.

Table 2. Typology of the relationship between political agency and crisis.

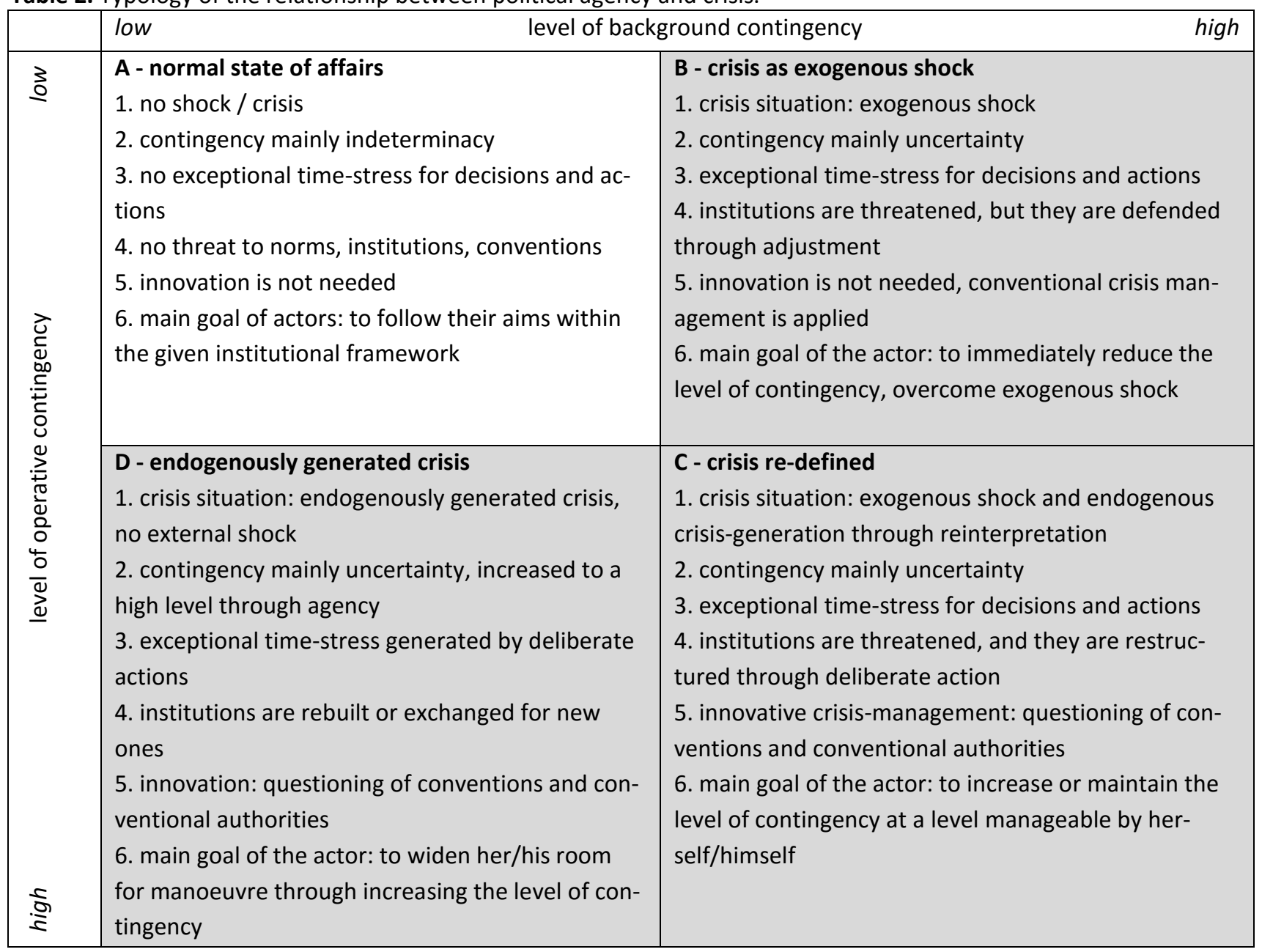


A high level of background contingency is present in quadrants B and C. By background contingency we mean events that cast doubt on conventions and which are exogenous from the point of view of the political agent. ${ }^{4}$ The best examples of exogenous shocks are a global economic crisis, a natural catastrophe, or a declaration of war by another country.

Sense- and meaning-making in crisis situations always have an important role. But when rules and norms are in doubt, the interpretation of the situation by political leaders gains extraordinary importance (cf. Boin et al., 2005, 2008; Hall, 1993), which enhances the role of leadership and political agency. When there is a crisis, leadership always has a choice, in an analytical sense, between attempting to read events within the frame of the existing paradigm, thus trying to reduce contingency immediately, and challenging them and presenting a new paradigm that offers a new meaning of what is going on. Therefore, quadrants $B$ and $C$ can be seen as two different strategies for "crisis exploitation" (Boin et al., 2008), articulated at the level of political theory. The main difference between our approach and previously cited literature on crisis management is that we take into account the possibility of political actors deliberately increasing the stakes (threat), contingency (uncertainty), and the state of emergency (urgency) in a crisis situation, for example through political actions or interpretation. We assume that the type of crisis mostly depends on interpretation, meaning-making, therefore a crisis triggered by an exogenous factor might be brought either into quadrant $B$ or into quadrant $C$ by political agency (redefinition). Endogenous crisis generation in quadrant $D$, however, is a case in which crisis is not just interpreted or re-defined, but invented. ${ }^{5}$

Unlike quadrants $A$ and $B$, an elevated level of operative contingency is present in quadrants $\mathrm{C}$ and $\mathrm{D}$. We speak of operative contingency when the political actor deliberately acts or speaks in such a way as to heighten the level of uncertainty, e.g. by questioning conventions or conventional authorities, the existing legal order, etc. The latter often entails a paradigm change (Hall, 1993; cf. Blyth, 2013) ${ }^{6}$, i.e. a dramatic

\footnotetext{
${ }^{4}$ Here, we stick once again to Palonen, adopting the viewpoint of "politics-as-activity" instead of "politics-as-sphere" (Palonen, $2003,2014)$. Acts of other political actors and consequences of their acts are exogenous to a concrete political actor in an activity-view, while they would be endogenous within the "sphere of politics".

${ }^{5}$ Our approach can be considered as a constructivist viewpoint, which while not ruling out differences between types of crises concerning their interpretability, assumes that all of them can be shaped by interpretation to a certain degree.

${ }^{6}$ Drawing on Hall, by paradigm we mean an interpretative framework of policymaking. "Policymakers customarily work within a framework of ideas and standards that specifies not only the goals of policy and the kind of instruments that can be
}

change in policy-making, comparing to policy adjustment (change of settings) or policy reforms (change of instruments, institutions).

In what follows, each type of relationship between political agency and crisis will be explored and a few examples will be provided to highlight the main features thereof.

\subsection{Quadrant A: Normal State of Affairs}

Quadrant A represents the normal state of affairs, when both background and operative contingency is low, or "normal". No shock or crisis happens, there is no threat to institutions or conventions, and there is no exceptional time-pressure for decisions and actions in the political process. Government policies typically change only slowly and incrementally through adjustment to the policy line of the incumbents or as reactions to the changing circumstances of the given policy area. The changes in the political process are usually not evenly distributed, therefore even the "normal" level of contingency is not a constant, but a fluctuating phenomenon. For example, the democratic succession of rulers usually increases the level of contingency, because early, and even regular elections cause indeterminacy in domestic politics. However, it is within the "normal" level of contingency which prevails in the parliamentary form of government. In other words, "rules and duties", norms and convention are not usually under threat in these cases. Uncertainty is limited to the composition of the next parliament or government. Although there may be changes in public policies, so contingency may rise to a higher level compared to the periods between two elections, this is expected and accepted as "normal" and falls within the boundaries of the predictable way of policy change in parliamentary regimes. One example of the remarkable presence of contingency in the normal state of affairs is the French Fourth Republic up to the 1958 crisis. $^{7}$ In one of the most penetrating recent French histories Marcel Merle (1999, pp. 975-976.) argues that under this regime:

"governmental instability did not always result in political instability....Governmental instabilities were mainly part of a relative continuity, almost making governmental crises into a means of governing."

used to attain them, but also the very nature of the problems they are meant to be addressing", states Hall (1993, p. 279.). Policy-paradigm is a lense for perceiving problems, a way of cognition of the world and an attitude to the potential modes of dealing with it. Hence, by paradigm change we mean the change of the hierarchy of overarching goals guiding policy.

${ }^{7}$ The First Republic in Italy (1948-1992) can be a similar example for contingency as normal state of affairs. 
In his account, the collapse of the Fourth Republic was due not to the frequent governmental changes, but to the regime's inability to decide in colonial issues.

\subsection{Quadrant B: Crisis as Exogenous Shock}

In quadrant B of our crisis typology, the exogenous shock that seems to question standard practices and policies is managed by the conventional means of crisis management. The political aim is to reduce contingency immediately. This could seem paradoxical, though only at first sight: although exogenous shocks always seem to cast doubt on conventional authorities and/or standard policy-lines, the nature and the gravity of the crisis is not self-evident, but open to debate and contestation. Crisis managers in quadrant B interpret the crisis as an anomaly rather than a systemic problem, which justifies their reliance on conventional means of crisis management.

Exogenous shocks, disasters and terrorist attacks all demand that leaders act immediately. We provide examples of prime ministers who had to face an economic crisis, a terrorist attack, and a natural catasthrope, respectively.

The best example of the strategy of technocratic or "crisis-managing" governments (McDonell \& Valbruzzi, 2014) is that of Mario Monti in Italy. Monti was asked to form a new government after Berlusconi's resignation on 12 November 2011. The ultimate purpose of Monti's technocratic government was to manage the Eurozone debt crisis in Italy. The main political parties in the Senate and Chamber of Deputies approved Monti's emergency austerity measures (increased taxes, labour market and pension reform) to steer Italy out of worsening economic conditions and to restore market confidence and financial stability. Although he promised to step down after the passing of the $\mathbf{2 0 1 2}$ Budget, he launched a centrist and liberal party called Civic Choice to run for election.

Spanish Prime Minister Jose María Aznar and his ruling Popular Party (PP) were challenged immediately before national elections (14 March 2004) by a series of bomb explosions on four trains heading to one of Madrid's main stations which killed 192 people and wounded 1,430. Until 11 March the governing party had held a comfortable 5 percent lead in the polls over rivals. Although the response of government was quick enough, the government misinterpreted the crisis situation and lost the "meaning-making race". The ruling party blamed the Basque separatist movement, ETA (Euskadi ta Askatasuna) for the terrorist attacks and, instead of facing the facts, doggedly kept to this narrative to the very end. The left-wing opposition Spanish Socialist Workers' Party (PSOE) easily managed to replace the official storyline with its own version, in which the bomb attacks were regarded a "punishment" by Al-Qaeda for military involvement in the Iraq war (even though the troops were sent on only a peacekeeping mission). After mass demonstrations with 11 million people (out of a population of 42 million) the PP lost the election (Olmeda, 2008).

\subsection{Quadrant C: Crisis Re-Defined}

In quadrant $\mathrm{C}$, the levels of both the background contingency and the operational contingency are high. That means: the political actor responds to an external shock not by applying conventional countermeasures, but instead the incumbent may "raise the stakes", interpreting the current circumstances not as an anomaly but as a systemic failure. It is important to note that this means not merely the rhetorical device of emphasizing or exaggerating the gravity of the crisis. That approach is always followed by the reassurance that we know the way out of crisis-which means: the situation is a serious one, but still just an anomaly, which can be cured by the application of the appropriate, routine familiar medicine. Instead of this strategy, our politician in quadrant $C$ (1) dramatizes the crisis in a more systematic way, and (2) couples this dramatization with the questioning of the prevailing policy-paradigm (Hall, 1993) or dominant public philosophy, Zeitgeist (Mehta, 2011) as well as the conventional authorities. To adopt a metaphor used earlier: while the politician in quadrant $B$ resembles a captain of a ship trying to escape the stormy conditions as quickly as possible, those in quadrants $C$ and $D$ consider the possibility that a storm is not necessarily a bad condition from the viewpoint of the captain. In cases $C$ and D leaders aim to create and/or maintain a high level of contingency, which can be mastered only by themselves (cf. Schabert, 1989).

We have two examples below for quadrant $C$ : the change of the American foreign- and security policy doctrine triggered by the $9 / 11$ crisis by President G. W. Bush and the unorthodox economic crisis-management of the extravagant Hungarian Prime Minister, Viktor Orbán.

Our first example for quadrant $C$ is the $9 / 11$ attack, which shook the American nation and created a crisis atmosphere for years. The rally round the flag effect provided unprecedented support for G. W. Bush in his new, war president role (Eichenberg, Stoll, \& Lebo, 2006; Hetherington \& Nelson, 2003): he became temporarily charismatic (Greenstein, 2008). President Bush gave a determined policy-answer, by setting up new authorities and agencies (Department of Homeland Security) as well as by passing through new legislation (US Patriot Act) and by using Presidential War Power, based on Constitutional tradition but also legitimized by Congressional authorization acts. The 9/11 attack was conventionally interpreted as an exogenous challenge which caused a so-called "incomprehensible crisis" (Boin et al., 2008, p. 19.), and which provided the incumbent with a relatively wide space for political in- 
terpretation and framing. The "War on Terror", and the "Axis of evil" were original frames for the Bush Doctrine, which turned out to be a new policy-paradigmit introduced a new era in the American foreign- and security policy and in international relations. The new policy included the concept of pre-emptive strikes, unilateralism and democratic regime change, which has some antecedents in American exceptionalism (Nagan \& Hammer, 2004). Bush transformed and extended his role as war president and turned it into an extensive executive unilateralism, using for example presidential signing statements extensively to suspend the application of Congressional laws in public administration (Galvin, 2009). The global "War on Terror" aimed to reduce background contingency. But the preventive military actions against terrorist suspects, the surveillance and detainment, the invasion of Afghanistan and Iraq, the replacement of a multilateral policy in international relations with unilateral US dominance (which caused a dissensus even within NATO) meant the increase of operative contingency in world politics. Bush continuously raised the stakes, but by 2005-2006 he lost support within Congress, was challenged by the Supreme Court, and for the last years of his presidency he became a lame duck.

Our second example is the Hungarian Prime Minister, Viktor Orbán's unorthodox financial policy from 2010 onwards. In contrast to the conventional crisismanagement of his predecessor, Gordon Bajnai, Orbán provided an unorthodox policy to stabilize the budget and to finance the sovereign debt. After his party Fidesz achieved a landslide victory, gaining $53 \%$ of the votes and more than two-thirds of the parliamentary seats in the 2010 general elections, Orbán used the opportunity to radically re-interpret both the nature of crisis and the suitable crisis-management. He framed his parliamentary "supermajority" in a quasirevolutionary context ("revolution in the pollingbooths") and relying on it he launched a new regime. As newly elected Prime Minister, first he introduced a dramatic crisis narrative (e.g. he compared Hungary to Greece) and applied new, innovative instruments to respond to the crisis. Although Orbán kept the budget deficit below $3 \%$ of GDP, which was a requirement of the European Union, he challenged a few conventional policy measures and questioned conventional authorities. In one parliamentary speech he announced:

"There is no one to copy, no example to follow. At this moment, there are no ready and useful textbooks, at best their contours are being sketched. The new recipes have to be invented by us, during our everyday struggles. It's a sweaty job." 8

\footnotetext{
8 Speech for Urgent and Topical Issues Debate, October 24th
} 2011. Retrieved from http://parlament.hu/internet/plsql/ogy_
Orbán inserted the problem of budget deficit and indebtedness into a broader crisis narrative in an innovative way. In this narrative he combined first, the international financial crisis of 2008, second, the domestic political crisis triggered by the former socialist Prime Minister, Gyurcsány's Őszöd "lying speech" in 2006 (which was accompanied with enduring antigovernment demonstrations and street violence), and third, the transformation in the world economy (globalized financial capitalism) and the decline of the European Union in a global context. Reframing the financial crisis from an exogenous to endogenous phenomenon, Orbán was able to instrumentalize the crisis to blame the left, the liberals, and international organizations like the IMF, and successfully legitimized the revolutionary measures he implemented after getting into power. Through his "freedom fight" Orbán refused to take new parts of the IMF credit line, and refused to accept the IMF and the EU advice on what fiscal and economic policy should be followed. Instead of reducing contingency through implementing the advised adjustment and policy-reforms accompanied by a new IMF loan, Orbán adopted a more risk-taking policy in financing sovereign debt. But this way, being freed from the control of international financial authorities (the IMF), Orbán gained a wider room for manoeuvre in domestic politics. ${ }^{9}$ Orbán framed his endeavours to reclaim Hungary's sovereignty vis-a-vis multinational firms, international financial institutions and banks as well as institutions such as the IMF and the EU. Conflicts with such actors increased uncertainty further, and this was exacerbated by the opening to the East and to Russia, which was detrimental to relations with the USA, though it ensured political support from Hungarians with strong national feelings. However, deepening conflicts and increasing contingency by political agency was a stratagem to create advantages in domestic politics. Therefore instead of bringing back the normalcy of the pre-crisis era, Orbán applied extraordinary measures on a permanent base. Instead of applying pure policy-adjustment to restore the situation ex ante, he developed new policies but also a wider political paradigm ${ }^{10}$ and successfully mobilized people to support it among the electorate. By and large, Orbán

naplo.naplo_fadat?p_ckl=39\&p_uln=122\&p_felsz=10\&p_szove $\mathrm{g}=\mathrm{v} \% \mathrm{E} 1 \mathrm{ls} \% \mathrm{E} 1 \mathrm{~g} \& \mathrm{p} \_$felszig $=10$

9 His revolutionary measures included crisis taxes on sectors like banking, telecommunication, or commercial industry, or reducing utility prices, but also a massive state intervention even in market and property relations, changing the relation between state and society and drafting and voting on a constitution.

10 Instead of policy-paradigm (Hall, 1993), which refers to a specific policy field, we can speak about an ideological or general political paradigm in Orbán's case, which includes the change in political thinking and philosophy of government in a more general sense. 
can be regarded an example of a politician who played not only against (background) contingency, but through (operative) contingency at the same time. In his 2014 Tusványos speech Orbán revealed his attitude towards contingency (as evidence for his view, he both mentions external shocks and policy measures of his government):

"we are living in a world in which anything can happen....It is practically impossible to forecast events precisely or within an insignificant margin of error."11

\subsection{Quadrant D: Endogenously Generated Crisis}

The situation presented by Quadrant $D$ is reflected only occasionally in the literature. In fact, it is the least obvious or tangible case in our typology. In quadrant $D$ there is no exogenous shock or external threat; the crisis is generated endogenously by political actors to broaden their room for manoeuvre. Uncertainty is increased to a high level through deliberate agency (operative contingency). There is an exceptional timestress generated by deliberate actions as well. The main goal of the key actor through these innovative actions is to question conventions and conventional authorities. The aim is not simply politicking but to change the balance of power, undermine their rivals' structural position, rebuild institutions or exchange them for new ones (e.g. constitution-making, revolutionary changes). Two examples are provided below to highlight the main features of endogenously generated crises.

Our first example is the "constitutional game" played by French president Charles de Gaulle in 1962 (Gaffney, 2010, pp. 40-44). By this year he had solved the Algerian question (though with a policy switch, rather than the way he promised), and the rebellion of the army was also not an issue anymore. In terms of our categories: the elevated level of background contingency that brought de Gaulle to power in 1958 was gone, the normal state of affairs seemed to be returning. In this political environment, he began to "stir up the calm waters" around himself. Firstly, he alienated his pro-European political allies (the Christian democratic MRP party) with his provocative anti-European speech on 15 May. His motives were clear: de Gaulle had a different vision of the republic to both his allies and his opposition. As Gaffney puts it: "1962 was a dramatic showdown between de Gaulle wanting to reinforce personality politics and almost everyone else trying to dedramatize the republic" (Gaffney, 2010, pp.

11 Prime Minister Viktor Orbán's Speech at the 25th Bálványos Summer Free University and Student Camp. Retrieved from http://www.kormany.hu/en/the-prime-minister/the-primeminister-s-speeches/prime-minister-viktor-orban-s-speech-atthe-25th-balvanyos-summer-free-university-and-student-camp
42). His strategy was to "move away from some forms of support, to move towards new policy positions" (Gaffney, 2010, p. 41). The second step in this process was the announcement of a referendum on the direct election of the president. After every party apart from his own united and overturned de Gaulle's prime minister, he dissolved the National Assembly, and scheduled the new elections after the referendum. He approached the people in an unconstitutional manner: "There was no basis in his own constitution for what he was doing; what he was doing was asserting the centrality of his own action" (Gaffney, 2010, p. 42). ${ }^{12}$ At the end, he clearly won his self-arranged showdown, triumphing both at the referendum and at the following elections. He successfully used operative contingency to ram through and solidify his political vision.

The second example for quadrant $D$ is Viktor Orbán's constitution-making and constitutional policy in Hungary between 2010 and 2014, which is an illuminating case for endogenous crisis-generation. But what counts as extraordinary in constitutional politics? Constitution-making is extraordinary by definition, since it means changing the "rules of the game", when the usually invisible pouvoir constituent (constitutionmaking power), i.e. the political sovereign, comes to the fore to be activated (Ackerman, 1998). This exceptional power, however, is supposed to withdraw and give way to normal politics again, after it has done its work. Therefore, constitutional politics is also a form of extraordinary situations, like crisis, when the existing norms, institutions and rules are under threat, a high level of contingency is present, and therefore there is an urgency to re-establish stability according to the scheduled new order. However, the extraordinary qualities of constitution-making - threat, contingency and urgency - can be reduced to a minimum, if it is carried out by an inclusive political consensus of the major political actors, elite groups and other stakeholders. ${ }^{13}$ This way, constitution-making can be tamed: contingency is reduced and it is pushed back to the world of normal politics, i.e. to quadrant $A$ in our typology. The constitutional policy of Orbán, however, was far from this "domesticated", consensual version of policymaking. The unilateral constitutional changes and the accompanying legislation modified the balance of powers, curtailed the power of control institutions like the Constitutional Court and the ombudsman, weakened the independence of the judiciary and introduced a more majoritarian electoral system. It also changed the relation between state and society and weakened

12 This unconstitutional strategy clearly separates the case from quadrant A. De Gaulle's strategy clearly transgressed the normal state of affairs.

13 A consensual constitution-making can be a long-lasting process, where there is time for deliberation and/or bargaining of the parties, in order to reduce contingency and threat. 
the separation of Church and State. All of these changes, which were carried out in a style of emergency legislation, threatened the social and political status quo of post-communist politics, and questioned the conventions and conventional authorities of the post-1990 Hungarian regime. This constitutional revolution was neither the consequence of an external shock, nor that of a deep internal constitutional crisis. It was endogenously generated by Orbán's creative political leadership and framing of the situation. Through the policy of permanent constitutional amendments and legislative dumping Orbán kept the level of contingency high and widened his room for manoeuvre to such a great extent as was unprecedented in Hungary since the 19891990 democratic transition.

\section{Conclusions}

This paper aimed to investigate the relation between contingency and political agency. Institutions, including norms, conventions and even the Zeitgeist are usually regarded as constraints of agency. In crisis, however, institutions become malleable and may be shaped by political agency. What is an institutional constraint for most political actors is often formed and generated through operative contingency by political agency, as our examples for endogenous crisis-generation and the re-definition of the crisis confirmed. Contingency too can be both a problem to overcome or a means of political action. Why, in fact, do creative leaders increase contingency? As we have seen, to increase contingency might have strategic purposes, such as: to widen their room for manoeuvre; to question the prevailing policyparadigm or dominant public philosophy and to offer a new paradigm of interpretation of the crisis; to delegitimize or blame conventional authorities; to offer / apply a new kind of crisis-management; to restructure power relations.

The role of contingency depends on the abilities and goals of the political actor who faces the crisis situation (or creates one). Technocrats, like Monti, were trying to "erect defences and barriers" against fortuna, while the agency of de Gaulle or Orbán can rather be characterized as "boring the hard boards" of the institutional arrangement, economic conventions, and authorities. As we saw in their cases, political leaders can not only utilize the higher level of contingency to create a new arrangement (a new state of normalcy) shaped to their wants; they can also try to incorporate an elevated level of contingency into everyday politics, making the state of exception permanent.

This paper aimed to contribute to the field at two levels. On the theoretical one, two contributions can be emphasized. Firstly, we introduced a conceptual typology that offers an overview of the approaches dealing with the relationship between crisis and political agency. This typology in our view can to a certain ex- tent alleviate the stark distinction between structure and agency through using the same concept (that of contingency) to describe both of them. Contingency, as we have seen, can be a constraining element of the structure that forces the politician to take a certain course of action (background contingency). But at the same time it can become operative, if the political actor wants and is able to take risk (Weber), or continually makes order and recreates chaos (Schabert, 1989). The views of Schabert and Weber point toward a "monist" understanding of political action, where contingency permeates everything and where it is both the barrier to and an element of agency. This view can be contrasted with the "dualist view", where structures and agency are starkly separated, and contingency is a feature of the structure, and the only task of political agency can be to abate it. Secondly, the aim of the typology was not just to add another theoretical perspective to the existing ones (it was not just an end in itself), but it also served as means to call attention to a potential relationship between agency and crisis that has been largely passed over by literature. This relationship is the most voluntaristic-and the "most clearly Weberian" - one, where there is no exogenous shock present, and leaders generate crisis situations themselves (quadrant D).

On the empirical level, two contributions can be mentioned again. Firstly, our typology seems to be useful in comparing different strategies of politicians in roughly similar settings. Monti and Orbán both had to tackle economic consequences of the European sovereign debt crisis and the Great Recession, following from the global financial crisis of 2007-08. Although differences in the structural context could be important to different actor strategies, in this case, the difference between strategies is so profound that only structural factors could not account for it. While Orbán incorporated the economic problems into a wider civilisational crisis-narrative, thereby adding operative contingency to the shakiness of international economic background to legitimate extraordinary measures, Monti's strategy was to immediately reduce background contingency by applying to the conventional best practice of economic crisis management. The same can be said about the difference between the Bush and the Aznar case. While the former succeeded in widening his room for manoeuvre after the 9/11 attacks by introducing the "war on terror" narrative to legitimate the policy change initiated later, Aznar sticked to the conventional Spanish governmental reactions after a terrorist attack by blaming ETA to defend his political position in the Iraq war. This difference between situations meant serious consequences for leaders.

Secondly, by shortly analyzing the cases of de Gaulle and Orbán in quadrant D, we tried to highlight a specific type of voluntaristic crisis generation under democratic circumstances: that of the "constitutional 
game". We should end with two further remarks on these cases. On the one hand, it could be an interesting task both for leadership studies and democratic theory to uncover further types of voluntaristic crisis generation in modern democracies. On the other hand, the differences between these "constitutional games" could also be worth further research. We touched only on one difference: while de Gaulle increased operative contingency only for a short period, to arrange a "showdown" with his political opponents and to introduce a new state of normalcy, Orbán tried to make the elevated level of contingency permanent, thereby converting the Hungarian constitutional settlement into some kind of a perpetuum mobile.

\section{Acknowledgements}

We wish to thank our colleagues at the Institute for Political Science, Centre for Social Sciences, Hungarian Academy of Sciences, the editors of this issue, and the anonymous reviewers for their helpful comments and suggestions. The usual disclaimer applies.

\section{Conflict of Interests}

The authors declare no conflict of interests.

\section{References}

Ackerman, B. (1998). We the People: Transformations. Cambridge, MA: Harvard University Press.

Blondel, J. (1987). Political leadership: Towards a general analysis. London: Sage Publications.

Blyth, M. (2003). Structures do not come with an instruction sheet: Interests, ideas, and progress in political science. Perspectives on Politics, 1, 695-706.

Blyth, M. (2013). Paradigms and paradox: The politics of economic ideas in two moments of crisis. Governance, 26(2), 197-215.

Boin, A., McConnell, A., \& 't Hart, P. (Eds.). (2008). Governing after crisis: The politics of investigation, accountability and learning. Cambridge, MA: Cambridge University Press.

Boin, A., 't Hart, P., Stern, E., \& Sundelius, B. (2005). The politics of crisis management: Public leadership under pressure. Cambridge, MA: Cambridge University Press.

Buller, J., \& James, T. S. (2015). Integrating structural context into the assessment of political leadership: Philosophical realism, Gordon Brown and the Great Financial Crisis. Parliamentary Affairs, 68(1), 77-96.

Corwin, R. G. (1978). Power. In E. Sagarin (Ed.), Sociology: The basic concepts (pp. 65-85). New York: Holt, Rinehart \& Winston.

Cronin, T. E. (1980). The state of the presidency. Boston: Little, Brown.

Edinger, L. J. (1967). Editor's introduction. In L. J. Edinger
(Ed.), Political leadership in industrialized societies (pp. 1-25). New York: Wiley.

Edinger, L. J. (1975). The comparative analysis of political leadership. Comparative Politics, 7(2), 253-269.

Eichenberg, R. C., Stoll, R. J., \& Lebo, M. (2006). War president: The approval ratings of George W. Bush. Journal of Conflict Resolution, 50(6), 783-808.

Gaffney, J. (2010). Political leadership in France: From Charles de Gaulle to Nicholas Sarkozy. Basingstoke: Palgrave Macmillan.

Galvin, D. (2009). Presidential practices after 9/11: Changes and continuities. In P. Roberts, M. Renyi, \& Y. Xunhua (Eds.), Change and continuity: The United States after 9/11 (pp. 271-305). Beijing: Beijing World Affairs Press.

Genovese, M. A. (1979). Democratic theory and the emergency powers of the president. Presidential Studies Quarterly, 9(3), 283-289.

Greenstein, F. I. (2008). The 'strong leadership' of George W. Bush. International Journal of Applied Psychoanalytic Studies, 5(3), 171-190.

Grint, K. (2005). Problems, problems, problems: The social construction of 'leadership.' Human Relations, 58(11), 1467-1494.

Hall, P. A. (1993). Policy paradigms, social learning, and the state: The case of economic policymaking in Britain. Comparative Politics, 25(3), 275-296.

Hargrove, E. C. (2004). History, political science and the study of leadership. Polity, 36(4), 579-593.

Hay, C. (2002). Political analysis. Basingstoke: Palgrave Macmillan.

Heifetz, R. A. (1994). Leadership without easy answers. Cambridge, MA: Harvard University Press.

Hetherington, M. J., \& Nelson, M. (2003). Anatomy of a rally effect: George W. Bush and the war on terrorism. PS: Political Science \& Politics, 36(1), 37-42.

Hook, S. (1957). The hero in history: A study in limitation and possibility. London: Secker \& Warburg.

Jones, B. D. (1989). Causation, constraint and political leadership. In B. D. Jones (Ed.), Leadership and politics. New perspectives in political science (pp. 3-14). Lawrence, KS: University Press of Kansas.

Kellerman, B. (1984). Leadership as a political act. In B. Kellerman (Ed.), Leadership: Multidisciplinary perspectives (pp. 63-89). Englewood Cliffs, NJ: PrenticeHall.

Machiavelli, N. (2008). The Prince. Indianapolis, IN: Hackett Pub. Co.

Masciulli, J., Molchanov, M. A., \& Knight, W. A. (2009). Political leadership in context. In J. Masciulli, M. A. Molchanov, \& W. A. Knight (Eds.), The Ashgate research companion to political leadership (pp. 3-27). Farnham, Surrey, UK: Ashgate.

McDonnell, D., \& Valbruzzi, M. (2014). Defining and classifying technocrat-led and technocratic governments. European Journal of Political Research, 53(4), 654-671. 
McFarland, A. S. (1969). Power and leadership in pluralist systems. Stanford, CA: Stanford University Press.

Mehta, J. (2011). The varied roles of ideas in politics: From 'whether' to 'how'. In D. Béland \& R. H. Cox (Eds.), Ideas and politics in social science research (pp. 23-46). New York: Oxford University Press.

Merle, M. (1999). Les institutions et la vie politique de 1945 à 1980. In G. Duby (Ed.), Histoire de la France des origines à nos jours (pp. 966-992). Paris: Larousse.

Nagan, W. P., \& Hammer, C. (2004). The new Bush national security doctrine and the rule of law. Berkeley Journal of International Law, 22(3), 375-438.

Nye, J. S., Jr. (2008). The powers to lead. Oxford: Oxford University Press.

Oakeshott, M. (1990). On human conduct. Oxford: Clarendon Press.

Oakeshott, M. (1991). Political education. In M. Oakeshott, Rationalism in politics and other essays (pp. 43-69). Indianapolis: Liberty Fund.

Olmeda, J. A. (2008). A reversal of fortune: Blame games and framing contests after the $3 / 11$ terrorist attacks in Madrid. In A. Boin, A. McConnell, \& P. 't Hart (Eds.), Governing after crisis: The politics of investigation, accountability and learning (pp. 63-84). Cambridge, MA: Cambridge University Press.

Palonen, K. (1998). Das "Webersche Moment": Zur Kontingenz des Politischen. Opladen, Germany: Westdeutscher Verlag.

Palonen, K. (2001). Politik statt Ordnung: Figuren der Kontingenz bei Max Weber. In H. J. Lietzmann (Ed.), Moderne Politik: Politikverständnisse im 20. Jahrhundert (pp. 9-21.). Opladen, Germany: Leske + Budrich.

Palonen, K. (2003). Four times of politics: Policy, polity, politicking, and politicization. Alternatives, 28(2), 171-186.

Palonen, K. (2014). The struggle with time. A conceptual history of 'politics' as an activity. London: LIT Verlag.

Philp, M. (2007). Political conduct. Cambridge, MA: Harvard University Press.

Pocock, J. G. A. (1975). The Machiavellian moment: Florentine political thought and the Atlantic republican tradition. Princeton, NJ: Princeton University Press.

Rossiter, C. L. (1948). Constitutional dictatorship: Crisis government in the modern democracies. Princeton, NJ: Princeton University Press.

Schabert, T. (1989). Boston politics. The creativity of power. Berlin: Walter de Gruyter \& Co.

Schedler, A. (2007). Mapping contingency. In I. Shapiro \& S. Bedi (Eds.), Political contingency: Studying the unexpected, the accidental, and the unforeseen (pp. 5478). New York: New York University Press.

Skinner, Q. (2002). Republican virtues in an age of princes. In Q. Skinner, Visions of politics, vol. II: Renaissance virtues (pp. 118-159). Cambridge, MA: Cambridge University Press.

't Hart, P., \& Rhodes, R. A. W. (2014). Puzzles of political leadership. In R. A. W. Rhodes \& P. 't Hart (Eds.), The Oxford handbook of political leadership (pp. 418433). Oxford: Oxford University Press.

Tocqueville, A. (1896). The recollections of Alexis de Tocqueville. New York: The MacMillan Co.

Tucker, R. C. (1968). The theory of charismatic leadership. Daedalus, 97(3), 731-756.

Tucker, R. C. (1981). Politics as leadership. Columbia: University of Missouri Press.

Weber, M. (2001). Politics as a vocation. In H. H. Gerth \& C. W. Mills (Eds.), From Max Weber: Essays in sociology (pp. 77-128). London: Routledge.

Widmaier, W. W., Blyth, M., \& Seabrooke, L. (2007). Exogenous shocks or endogenous constructions? The meanings of wars and crises. International Studies Quarterly, 51(4), 747-759.

\section{About the Authors}

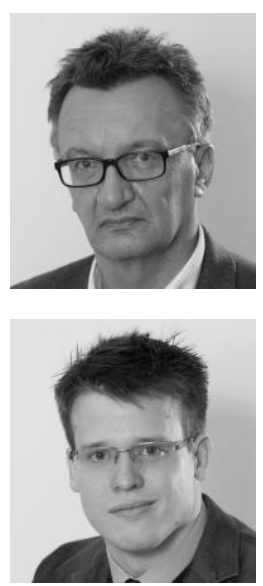

András Körösényi, MA, PhD (Budapest) holds a Research Chair at the Institute for Political Science, Centre for Social Sciences, Hungarian Academy of Sciences and he is Professor of Political Science at the Corvinus University of Budapest. His publications include Towards Leader Democracy (2012, coauthor), Political Leadership in Liberal and Democratic Theory (2009, co-editor). His current research interest includes political leadership, theory of democracy, and Hungarian politics.

Gábor Illés (Budapest) is a Junior Research Fellow at the Institute for Political Science, Centre for Social Sciences, Hungarian Academy of Sciences, and an Assistant Lecturer at the Institute of Political Sciences, Faculty of Law, Eötvös Loránd University. His research interests include political leadership, realism in political theory, and political discourse. He is writing his dissertation about the problem of political action in realist political theory. 


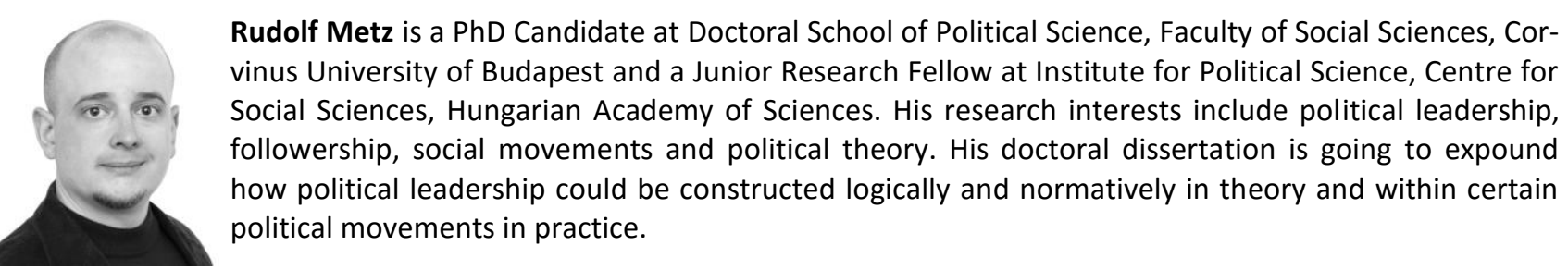

Rudolf Metz is a PhD Candidate at Doctoral School of Political Science, Faculty of Social Sciences, Corvinus University of Budapest and a Junior Research Fellow at Institute for Political Science, Centre for how political leadership could be constructed logically and normatively in theory and within certain political movements in practice. 